\title{
弦材が構面外座屈する鋼管トラ又梁の変形能力に関する研究 DEFORMATION CAPACITY OF LATERALLY BUCKLED TUBULAR TRUSS GIRDERS
}

\author{
前田珠希*, 小川厚治**, 黒羽 啓明** \\ Tamaki MAEDA, Koji OGAWA and Yoshiaki KUROBANE
}

\begin{abstract}
In this paper, the behavior of tubular trusses after out-of-plane buckling of chords is analyzed by using the elasto-plastic-pointhinge approach developed by the authors. The results show that plastic deformation tends to concentrate on the end segments of the chords and that the post-buckling load-deformation curves are stabler than those of centrally loaded columns with the same slenderness ratios. From these results, a formula is derived for evaluating the deformation capacity of lattice girders under antisymmetrical bending. This formula indicate that rather stringent limitations on both thickness and slenderness ratios are required so that lattice girders have a satisfactory deformation capacity.
\end{abstract}

Keywords : truss, circular tube, post-buckling behavior, lateral buckling, deformation capacity トラス，円形鋼管，座屈後挙動，構面外座屈，変形能力

\section{1. 序}

重層骨組の大梁として充腹材の代わりに用いられることを想定し た卜ラス梁の座屈後挙動、変形能力については、既に多くの研究が あり 1-5)、文献6)には一定の変形能力を確保するための設計条件も提 示されている。しかし、それらは主に開断面材で構成され弦材が構 面内に座屈するトラスに関するもので、弦材の構面外座屈後挙動、 円形鋼管部材の座屈後軸方向変形能力については、未だ十分な検討 が行われていない。

トラス梁に比較的大きな塑性変形能力を付与するには、座屈する 弦材の有效細長比を 20 程度以下の極端に小さい值に制限する必要の あることは、既に指摘されているの。鋼管トラス弦材の横補剛間で の細長比は通常かなり大きいが、ウェブ材や引張側弦材などの拘束 効果7,8)や、横補剛間の複数区間で軸力が変動することによる効果、 および、軸力変動に伴って各区間の接線倸数が変動することによる 効果9などによって、鋼管トラス弦材の座屈長さは横補剛間距離よ りかなり短くなることが明らかにされて㧍り、その実用的な座屈長 さ算定式も提案されている。また、筆者らは既に、極短柱加長柱 までの円形鋼管部材の座屈後挙動を予測できる簡略な解析法を提案 し、冷間成形円形銅管部材が曲げ座屈した後、局部座屈が生じるま
での軸方向変形能力についても実験值の良好な近似が得られること を報告している10)。

曲げモーメント勾配のある鋼管トラス梁に扔いて弦材が構面外に 座屈すると、塑性変形は最大压縮軸力を受ける端部1区間の弦材に 集中する6,11)。したがって、本論では、中心圧縮柱について提案し た上記解析法を抎張して、鋼管トラス弦材の端部1区間の座屈後挙 動について検討すると共に、冷間成形円形鋼管部材で構成され弦材 が構面外に座屈するトラス梁を対象に、その変形能力の実用的な算 定式を提案する。

\section{2. トラスの座屈後挙動予測式}

本節では、構面外座屈する鋼管トラス端部弦材の座屈後挙動予測 式を導く。この解析は、中心圧縮柱について既に筆者らが提案して いるもの ${ }^{10}$ と同様であるが、その手順を以下に簡単に示しておく。

2.1 解析モデルと仮定

ここでは、その座屈後変形を図1に模式的に示しているような弦 材端部がピン支持されたトラスと端部が固定のトラスを対象にす る。ただし、いずれについてもははここで解析対象とする端部1区間 の弦材の長さであり、 $L$ は横補剛間距離である。解析仮定を以下に

本論文の一部は日本建築学会中国・九州支部研究報告, 1996.3に発表している。

* 大和八门ス工業侏 $)$ 工修

** 熊本大学工学部建築学科 教授. 工博 
示す。

[1] トラス弦材の有効座屈長さ $l_{k}$ は既知とする。

[2] 弦材は、端部弦材の軸力が有効座屈長さ $l_{k}$ に応じた接線係数荷重 $N_{t}$ に達すると曲げ座屈する。

[3] 弦材の座屈後変形を図2のようにモデル化し、弦材の曲げ変形は 弾塑性ヒンジのみに生じるとする。ただし、弾塑性ヒンジは、端 部ピン支持トラスでは材端から $l_{k} / 2$ 離れた位置に仮定し、端部固 定トラスでは材端と材端から $l_{k}$ 離れた位置の2箇所に仮定する。

[4] 弾塑性ヒンジの変形（回転角 $\theta_{h}$ と軸縮み $U_{h}$ ) と弾塑性ヒンジ位 置での断面の変形（曲率 $\phi$ と重心軸歪度 $\varepsilon_{h}$ ) の比は、次式で示す 一定值 $l_{h}$ とする。

$$
\begin{aligned}
& \theta_{h}=l_{h} \phi \quad, \quad U_{h}=l_{h} \varepsilon_{h} \\
& l_{h}=\theta_{h} / \phi=\frac{4}{\pi^{2}} l_{k}
\end{aligned}
$$

ここで、 $l_{h}$ はヒンジ長さと定義する量である。

[5] 弾塑性ヒンジに作用する曲げモーメント $M$ と軸力 $N$ は次式の降 伏条件式を満足する。

$$
\frac{M}{\sigma_{c} Z_{p}}+\left(\frac{N}{\sigma_{c} A}\right)^{2}=1
$$

ただし、式中の $Z_{p}$ は塑性断面係数、 $A$ は断面積を表す。また、 $\sigma_{c}$ はヒンジの硬化特性を表す応力度で、断面重心より圧縮側に断面 二次半径 $i$ だけ離れた位置での応力度である。

[6] 断面の塑性歪度は、図3に示すように直線的に変化するものとす る。ただし、図3で $\varepsilon_{p \downarrow}$ は接線係数荷重時の塑性歪度である。

[7]材料は非線形歪硬化弾塑性体とし、その応力度 $\sigma$-塑性歪度 $\varepsilon_{p}$ 関 係は、次の関数で表せるとする。

$$
\sigma=f\left(\varepsilon_{p}\right), \varepsilon_{p}=f^{-1}(\sigma)
$$

[8] 断面の最外縁歪度 $\varepsilon_{p s}$ が短柱圧縮試験の局部座屈発生時歪度 $\varepsilon_{m}$ に達したとき、局部座屈が発生する。

序でも述べたように鋼管トラス弦材の構面外座屈長さの算定式に ついては既に多くの提案がある7-9)。仮定[1]は、本解析が、そのよう な既往の算定式から求めた座屈長さの利用を前提としていることを 示している。

また、銅管部材の座屈軸力は接線係数理論による解析で予測でき ることは既に明らかにされており12,13)、仮定[2]はこれに基づいてい る。
図1,2にも示しているように、弦材にはウェブ材から弦材軸方向 力とともに構面外变形を拘束するような力が作用し、左端の支持点 には軸方向力 $N$ のほかに構面外方向反力 $V$ 、更には構面外曲げ モーメント $M$ が生じる。その結果、最大圧縮軸力を受ける左端弦 材は、図1,2中の鎖線軸方向の力 $N^{\prime}$ のみを受けることになり、この 鎖線軸に関するたわみの半波長の長さを座屈長さ $l_{k}$ としている。こ のような座屈後挙動を表す座屈長さ $l_{k}$ は、座屈軸力を計算するため に通常用いられている座屈長さ、言い换えると座屈発生時の変形性 状を表す座屈長さとは必ずしも一致しない。むしろ、最大圧縮軸力 を受ける弦材部分は座屈後塑性化が進行するのに対して、その他の 部分は応力低下によって除荷するので、周辺部分の拘束効果は座屈 後さらに大きくなり、座屈長さは変形が進むにつれて短くなる。し たがって、座屈後挙動を表す座屈長さ $l_{k}$ としては、座屈軸力計算用 の座屈長さが近似值、または上限值として利用できると考えて、仮 定[3]を採用している。

仮定[4]から[8]は、文献10)で中心圧縮柱に関して採用したものと 同じである。

\section{2 座屈弦材の座屆後挙動予測式 \\ 2.2.1 端部ピン支持弦材}

図2(a)は端部ピン支持弦材の解析モテルである。この図に示す幾 何学的関係と 2.1 節の仮定を基に端部弦材の座屈後軸力-軸方向変形 関係を算定するが、式の誘導は基本的には文献10)の中心圧縮柱の 場合と同じであるので、実際の計算に必要な式だけを列挙する。

トラス端部弦材の座屈後軸力 $N$ は次式のようになる。

$$
\begin{gathered}
N=\frac{A \sigma_{c}}{\sqrt{c_{2}{ }^{2} \lambda^{2} \theta_{1}{ }^{2}+1}+c_{2} \lambda \theta_{1}} \\
\text { ただし、 } c_{2}=\frac{\pi}{8 \sqrt{2}(2-k)}, k=l_{k} / L, \lambda=l_{k} / i
\end{gathered}
$$

ここで、 $A$ は弦材の断面積であり、 $i$ は断面2次半径である。降伏 曲面の硬化量を評価するための応力度 $\sigma_{c}$ に対応する塑性歪度 $\varepsilon_{p c}$ は 次式となる。

$$
\varepsilon_{p c}=\frac{\pi}{4 \lambda}\left(\frac{4 \sqrt{2}}{\sqrt{c_{2}^{2} \lambda^{2} \theta_{1}^{2}+1}+c_{2} \lambda \theta_{1}}+\pi\right) \theta_{p}+\varepsilon_{p t}
$$

弾塑性ヒンジの塑性回転角 $\theta_{p}$ は次式のようになる。

$$
\theta_{p}=\frac{2}{2-k}\left(1-\frac{N_{i}}{N_{e}} \frac{1}{\sqrt{c_{2}^{2} \lambda^{2} \theta_{1}^{2}+1}+c_{2} \lambda \theta_{1}}\right) \theta_{1}
$$

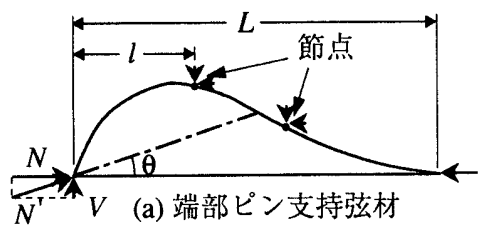

図1 弦材の構面外座屈変形

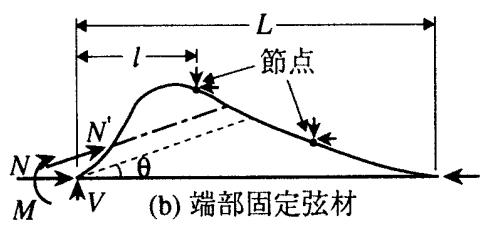

(b) 端部固定弦材

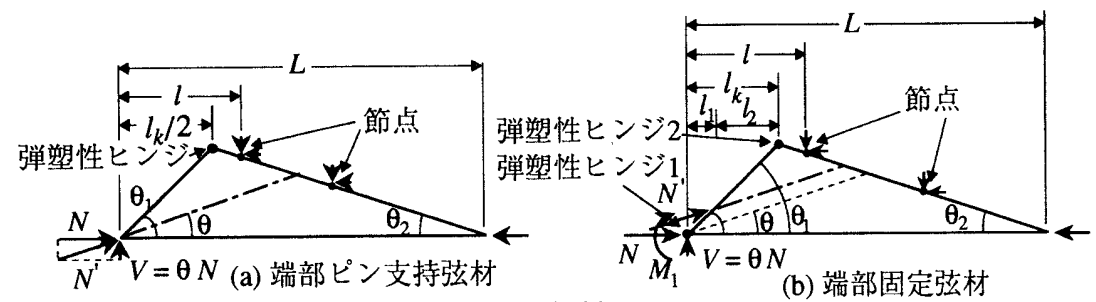

図2 解析モデル

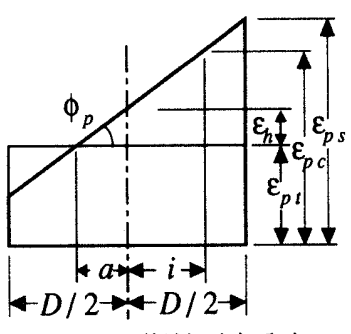

図3 塑性歪度分布 
ただし、 $N_{t}$ は接線係数荷重、 $N_{e}$ はオイラー荷重である。

トラスの端部弦材の全軸方向変形 $U$ は、軸方向弾性変形 $U_{e}$ 、最 大軸力までに生じる軸方向塑性変形 $U_{p}$ 、ヒンジでの軸方向塑性変 形 $U_{h}$ と横たわみによる軸方向変形 $U_{w}$ の和で表す。

$$
U=U_{e}+U_{p}+U_{h}+U_{w}
$$

ここで各軸方向変形成分は次式のようになる。

$$
\begin{aligned}
& U_{e}=\frac{N l}{E A}, \quad U_{p}=l f^{-1}\left(\frac{N}{A}\right) \\
& U_{h}=\frac{4 \sqrt{2} i}{\pi \sqrt{c_{2}^{2} \lambda^{2} \theta_{1}^{2}+1}+c_{2} \lambda \theta_{1}} \theta_{p} \\
& U_{w}=\frac{1}{4} l_{k} \theta_{1}^{2} \frac{2}{2-k}
\end{aligned}
$$

ただし、ここに示す $U_{p}$ の式は最大軸力に達するまでを適用範囲と し、軸力が減少する範囲では最大軸力時の軸方向塑性変形を用い る。

部材の局部座屈は、仮定[8]に従い予測する。図3に示す圧縮側最 外縁の塑性歪度 $\varepsilon_{p s}$ は次式で表される。

$$
\varepsilon_{p s}=\frac{\pi}{4 \lambda}\left(\frac{4 \sqrt{2}}{\sqrt{c_{2}^{2} \lambda^{2} \theta_{1}^{2}+1}+c_{2} \lambda \theta_{1}}+\frac{\pi D}{2 i}\right) \theta_{p}+\varepsilon_{p t}
$$

\subsection{2 端部固定弦材}

図2(b)は端部を固定した弦材の座屈後挙動の解析モデルである。 $l_{1}$ と $l_{2}$ の比は2つの弾塑性ヒンジの曲げモーメントの比であり、こ れを曲率の比で近似する。

$$
\begin{aligned}
& l_{1} / l_{2}=\sqrt{2(1-k)} \\
& l_{k}=l_{1}+l_{2}
\end{aligned}
$$

軸力 $N$ は弾塑性ヒンジ1の関係から導くと次式となる。

$$
N=\frac{A \sigma_{c 1}}{\sqrt{c_{3}^{2} \lambda^{2} \theta_{1}^{2}+1}+c_{3} \lambda \theta_{1}}
$$

ただし、

$$
c_{3}=\frac{\pi}{8 \sqrt{2}(1-k)} \frac{\sqrt{2(1-k)}}{1+\sqrt{2(1-k)}}
$$

ここで、 $k=l_{k} / L, \lambda=l_{k} / i$

弾塑性ヒンジ 1 の硬化量を評価するための応力度 $\sigma_{c 1}$ に対応する 塑性歪度 $\varepsilon_{p c 1}$ を求めると、次式となる。

$$
\begin{aligned}
\varepsilon_{p c 1} & =\frac{\pi}{4 \lambda} \frac{1+\sqrt{2(1-k)}}{\sqrt{2(1-k)}} \\
& \times\left(\frac{4 \sqrt{2}}{\sqrt{c_{3}{ }^{2} \lambda^{2} \theta_{1}^{2}+1}+c_{3} \lambda \theta_{1}}+\pi\right) \theta_{p 1}+\varepsilon_{p t}
\end{aligned}
$$

ここで、弾塑性ヒンジ 1 の塑性回転角 $\theta_{p 1}$ は次式となる。

$$
\theta_{p 1}=\left[1-\frac{4}{\{1+\sqrt{2(1-k)}\}^{2}} \frac{N_{t}}{N_{e}} \frac{1}{\sqrt{c_{3}^{2} \lambda^{2} \theta_{1}^{2}+1}+c_{3} \lambda \theta_{1}}\right] \theta_{1}
$$

また、弾塑性ヒンジ2の塑性回転角 $\theta_{p 2}$ は次式となる。

$$
\theta_{p 2}=\frac{1}{1-k} \theta_{p 1}
$$

弾塑性ヒンジ 1,2 の軸方向塑性変形を $U_{h 1}, U_{h 2}$ とすると、全軸方向 変形成分は次式で表される。

$$
U=U_{e}+U_{p}+U_{h 1}+U_{h 2}+U_{w}
$$

ここで各軸方向変形成分は次のようになる。

$$
\begin{aligned}
& U_{e}=\frac{N l}{E A} \quad, \quad U_{p}=l f^{-1}\left(\frac{N}{A}\right) \\
& U_{h 1}=\frac{4 \sqrt{2} i}{\pi \sqrt{c_{3}^{2} \lambda^{2} \theta_{1}^{2}+1}+c_{3} \lambda \theta_{1}} \theta_{p 1} \\
& U_{h 2}=\frac{4 \sqrt{2} i}{\pi \sqrt{c_{4}{ }^{2} \lambda^{2} \theta_{1}^{2}+1}+c_{4} \lambda \theta_{1}} \theta_{p 2} \\
& U_{w}=\frac{1}{2} l_{k} \theta_{1}^{2} \frac{1}{1-k} \\
& c_{4}=c_{3} / \sqrt{2(1-k)}
\end{aligned}
$$

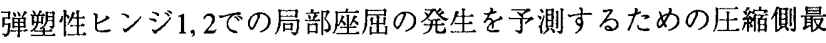
外縁の塑性歪度 $\varepsilon_{p s 1}, \varepsilon_{p s 2}$ は次のようになる。

$$
\begin{aligned}
\varepsilon_{p s 1} & =\frac{\pi}{4 \lambda} \frac{1+\sqrt{2(1-k)}}{\sqrt{2(1-k)}} \\
& \times\left(\frac{4 \sqrt{2}}{\sqrt{c_{3}^{2} \lambda^{2} \theta_{1}^{2}+1}+c_{3} \lambda \theta_{1}}+\frac{\pi D}{2 i}\right) \theta_{p 1}+\varepsilon_{p t} \\
\varepsilon_{p s} 2 & =\frac{\pi}{8 \lambda}(1+\sqrt{2(1-k)}) \\
& \times\left(\frac{4 \sqrt{2}}{\sqrt{c_{4}^{2} \lambda^{2} \theta_{1}^{2}+1}+c_{4} \lambda \theta_{1}}+\frac{\pi D}{2 i}\right) \theta_{p 2}+\varepsilon_{p t}
\end{aligned}
$$

\section{3 実験値との比較}

\section{1 概要}

本節では、2節で誘導した構面外座屈するトラスの座屈後挙動予 測式を既往の実験結果 ${ }^{13,14)}$ と比較する。比較に用いた試験体は、そ の概形を図4(a)に示すT4と、図4(b)に示すF2,F3で、寸法は表1に示 している。T4試験体の弦材端部は構面外にピン支持されており、 F2, F3 試験体の弦材端部は構面外回転が拘束されている。

解析に用いた応力度-歪度関係は各実験と並行して行われた短柱 圧縮試験の結果を次式に示すRamberg-Osgood関数で近似したもので ある。

$$
\varepsilon=\frac{\sigma}{E}+r\left(\frac{\sigma}{\sigma_{y}}\right)^{m}
$$

また、座屈弦材の局部座屈発生を判定する時に用いる最大歪度 $\varepsilon_{m}$ は、次の越智らの提案式15)より求めた。

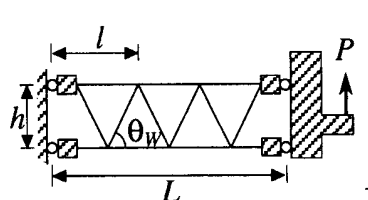

(a) $\mathrm{T} 4$

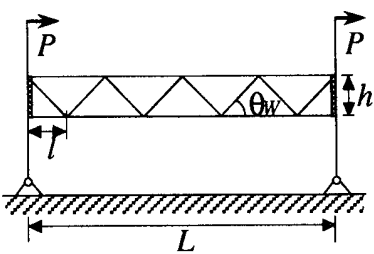

(b) F2,F3
図4 実験概要

表1 試験体寸法 (mm)

\begin{tabular}{|c|c|c|c|c|r|}
\hline 試験体 & $L$ & \multicolumn{1}{|c|}{$l$} & \multicolumn{1}{c|}{$h$} & $\theta_{W}$ & \multicolumn{1}{c|}{$l_{k}$} \\
\hline $\mathrm{T} 4$ & 5090 & 1827 & 1250 & $59.2^{\circ}$ & 2616 \\
\hline $\mathrm{F} 2$ & 5536 & 692 & 600 & $41.0^{\circ}$ & 364 \\
\hline $\mathrm{F} 3$ & 5536 & 692 & 600 & $38.5^{\circ}$ & 463 \\
\hline
\end{tabular}

表2 応力度-歪度関係

\begin{tabular}{|c|c|c|c|c|c|c|}
\hline \multirow{2}{*}{ 試験体 } & 断面実測寸法 & $\sigma_{y}$ & $E$ & $r$ & $m$ & $\varepsilon_{m}$ \\
\cline { 2 - 7 } & $\mathrm{mm}$ & $\mathrm{tf} / \mathrm{cm}^{2}$ & $\mathrm{tf} / \mathrm{cm}^{2}$ & $10^{-3}$ & & $10^{-2}$ \\
\hline T4 & $139.82 \phi \times 3.11$ & 3.67 & 2102 & 2.00 & 17.9 & 1.23 \\
\hline F2 & $101.65 \phi \times 2.94$ & 3.28 & 2131 & 2.01 & 12.5 & 1.86 \\
\hline F3 & $101.65 \phi \times 2.92$ & 3.18 & 2116 & 1.95 & 11.7 & 1.86 \\
\hline
\end{tabular}




$$
\varepsilon_{m}=\varepsilon_{y} 0.205\left(\varepsilon_{y} \frac{D}{T}\right)^{-1.39}
$$

これらの近似結果を表2に示している。なお、解析に用いた $\sigma_{y}, E$ の 值は上記のようにRamberg-Osgood関数近似より得た值で必ずしも参 考文献13,14)中の值と一致しない。

図5は、最大圧縮力を受ける端部弦材の軸力-軸方向変形関係で、 降伏時の軸力 $N_{y}$ 、軸方向変形 $U_{y}$ で無次元化している。各図中の 印は実験值で、印で目視の観察による局部座屈発生点を示してい る。また、太線は前節の方法による解析值で、○印で曲げ座屈発生 点を、・印で局部座屈発生点を示している。この図によると、前節 の方法による解析值は、実験における局部座屈発生までの軸力-軸方 向変形関係および局部座屈発生点をよく近似していることがわか る。特に、(b), (c) 図に示すF2, F3 試験体は基準化細長比が $0.13,0.16$ と 非常に小さいので、実験値は曲げ座屈後も軸力が低下することなく 変形を続け、局部座屈の発生によって軸力が低下し始めるが、この ような細長比の小さい弦材の局部座屈発生までの挙動についても、 解析値は良好な近似を与えている。

ここで示したような鋼管トラスの座屈後挙動については、塑性変 形は端部1区間の弦材に集中することは既に報告されているので11、 図5に示した端部弦材の軸力 $N / N_{y}$-軸方向変形 $U / U_{y}$ 関係を用 い、他の部材は弾性として、トラス架構全体の座屈後挙動を算定し た。ただし、F2, F3試験体の引張側端部下弦材の軸力 $N / N_{y}$-軸方向 変形 $U / U_{y}$ 関係は応力度-歪度関係と同じとしている。眓6はこのト ラス試験体全体の荷重-変形関係を示したもので、端部弦材が降伏す る時の荷重 $P_{y}$ および弾性変形 $\Delta_{y}$ で無次元化している。図6において も図5と同様に、実験における局部座屈発生点を○印で、解析におけ る局部座屈発生点をけ印で示しているが、図5では実験と解析両者の 局部座屈発生時の変形量が概ね一致しているのに対して、図6では解 析値の方が局部座屈発生時の変形量が小さくなっていることが注目 される。これは、解析では端部弦材以外の塑性変形を無視している ためである。特に、(a)図に示すT4試験体の実験では、ウェブ材と弦
材の分岐継手に明瞭な局部変形が認められている。端部弦材以外の 塑性変形を無視しているので、解析結果は局部座屈発生時の変形を 過小に評価する傾向があり、図6(a)のT4試験体については最大耐力 点以降の解析による荷重-変形曲線が実験值に比べ変形の小さい側 にシフトしているが、端部弦材以外の塑性変形を無視した解析値 は、ここで示した3つの試験体について、弦材が構面外座屈した後 の挙動の良好な近似を与えている。

図5には更に、細線で端部弦材と同一細長比を持つ中心圧縮柱の 軸力 $N / N_{y}$-軸方向変形 $U / U_{y}$ 関係を示しており、局部座屈発生 点を回印で示している。細長比が極端に小さいF2, F3試験体につい ては明瞭ではないが、この図によると、鋼管トラス弦材の座屈後挙 動は中心圧縮柱よりも座屈後の軸力低下が緩やかで、局部座屈発生 時の軸方向変形も大きいことが分かる。これは、無次元化軸力が同 ビ状態で、前節(8),(15)式に示した端部弦材の各軸方向成分を、文献 10)に示した中心圧縮柱に関する提案式と比べると、材全体に生じ る軸方向変形 $U_{e}+U_{p}$ には変化がないが、弾塑性ヒンジの軸方向塑 性変形 $U_{h}$ とたわみによる軸方向変形 $U_{w}$ のいずれもが端部弦材の

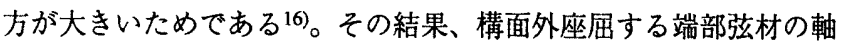
力 $N / N_{y}$-軸方向変形 $U / U_{y}$ 関係は、同じ細長比の中心圧縮柱よ り、座屈後の軸力低下が緩やかで、局部座屈発生時変形も大きくな る。

\section{4 トラス梁の変形能力}

\section{1 变形能力の算定方法}

ここでは、文献10)と同様に、局部座屈発生点を塑性変形の限界 と考えて、鋼管トラス梁の変形能力を定義する。すなわち、局部座 屈発生時变形を $\Delta_{c r}$ 、降伏時弾性変形を $\Delta_{y}$ とすると、変形能力 $\eta$ は 次式となる。

$$
\eta=\Delta_{c r} / \Delta_{y}-1
$$

上式で定義した变形能力 $\eta$ は、2節で示した解析から算定できる。

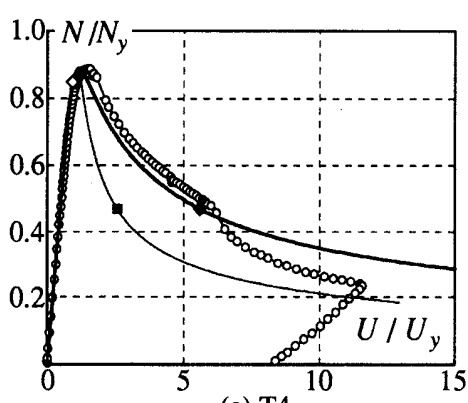

(a) $\mathrm{T} 4$

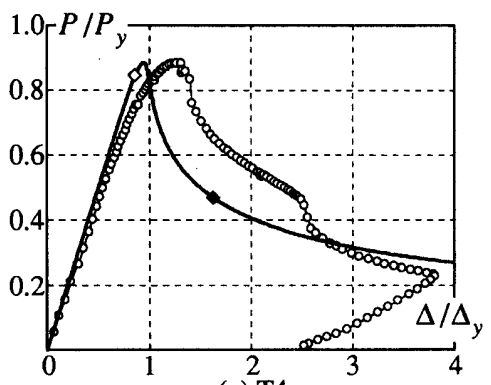

(a) $\mathrm{T} 4$

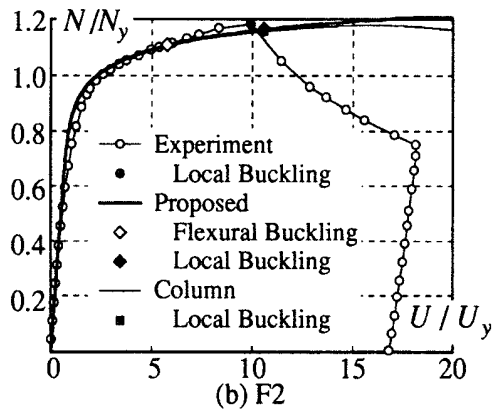

図5 端部弦材の軸力-軸方向変形関係

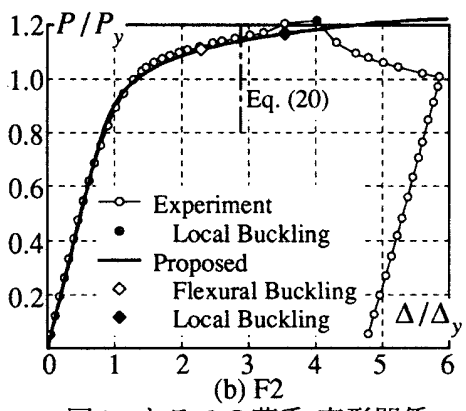

図6 トラスの荷重-変形関係

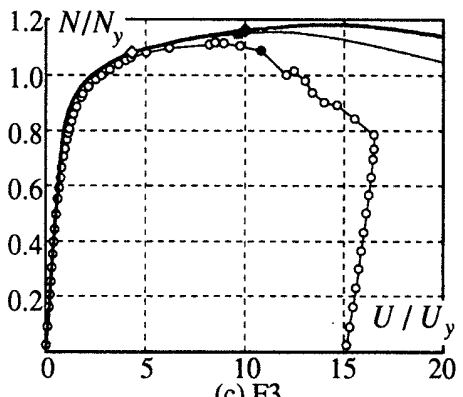

(c) F3

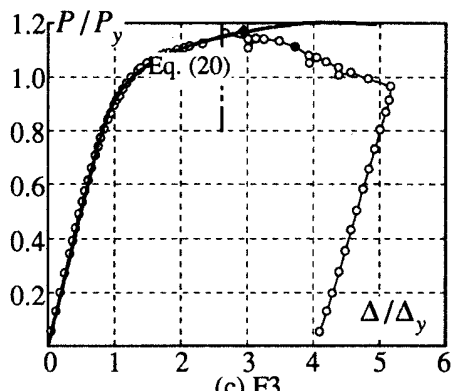

(c) $\mathrm{F} 3$ 
この節では、より実用的な変形能力の略算式を導く。

さて、四7(a)に示すような逆対称曲げを受け弦材が構面外座屈す るトラス梁を考え、前節の結果からトラス梁の変形能力を過小に評 価する安全側の仮定として、塑性校形は端部一区間の弦材のみに生 じると仮定する。また、この端部弦材の軸力-軸方向変形関係は圧縮 側、引張側いずれについても塑性化後は降伏軸力を保持する完全弾 塑性型と仮定する。このように仮定すると、図7(a)のトラス梁の変 形は塑性化後も逆対称となり、その片側部分の変形は図7(b)の片持 ち梁と同じになる。図7(b)の片持ち梁について、最大圧縮力を受け る第一下弦材の塑性変形能力を $\eta_{i}$ とすると、この部材の変形のみに よるトラスの載荷点変位 $\delta$ と荷重 $P$ の関係は図8(a)のように表され る。ただし、

$$
P_{y}=\frac{h}{2 n l} N_{y} \quad, \quad \delta_{y}=\frac{2 n l}{h} U_{y}
$$

第一下弦材が降伏すると荷重は変化せず、他の個材の変形はそれ以 上変化しないので、図7(b)のトラス梁の荷重 $P$-変形 $\Delta$ 関係は図8(b) のようになる。従って、トラス梁の変形能力 $\eta$ は次式となる ${ }^{3,4) 。 ~}$

$$
\eta=\frac{\eta_{i} \delta_{y}}{\Delta_{y}}=\frac{\delta_{y}}{\Delta_{y}} \eta_{i}=R_{E} \eta_{i}
$$

ここで、 $R_{E}$ はトラス梁の全体弾性変形に占める端部弦材の弾性変形 の割合であり、本論で寄与率と定義する量である。

\section{2 寄与率の算定}

図7(b)に示すワーレントラス梁の端部下弦材の奇与率を考える。 ただし、 $n$ はパネル数、lは端部弦材の長さであり、上弦材と下弦 材の断面は等しく、ウェブ材の断面はすべて同じであるとしてい る。

図7(b)のように荷重 $P$ を受ける場合、第 $i$ 上弦材の軸方向変形によ る載荷点での鉛直変位 $\delta_{U i}$ 、第 $j$ 下弦材の軸方向変形による載荷点 鉛直変位 $\boldsymbol{\delta}_{L_{j}}$ は次式となる。

$$
\begin{array}{ll}
\delta_{U i}=\left(n-i+\frac{1}{2}\right)^{2} \frac{8 l^{3}}{E A h^{2}} P & (1 \leq i \leq n) \\
\delta_{L j}=(n-j+1)^{2} \frac{8 l^{3}}{E A h^{2}} P & (2 \leq j \leq n)
\end{array}
$$

ただし、第一下弦材の場合は次式となる。

$$
\delta_{L 1}=n^{2} \frac{4 l^{3}}{E A h^{2}} P
$$

ウェブ材の変形による鉛直変位 $\delta_{B R}$ は次式となる。

$$
\delta_{B R}=\frac{1}{\sin ^{2} \theta} \frac{l_{W}}{E A_{W}} P
$$

(22)〜(25)式において、Eはヤング係数、 $A$ は弦材の断面積、 $A_{W}$ は ウェブ材の断面積、 $h$ は弦材重心間距離、 $l_{W}$ はウェブ材の長さ、 $\theta$ は弦材とウェブ材の交角である。

ウェブ材と弦材の分岐継手の変形による載荷位置での鉛直変位 $\delta_{K}$ は次式となる。

$$
\delta_{K}=P / E K
$$

ここで $K$ は分岐継手の俩性であり次式とする17)。

$$
K=1.43 D\left(\frac{T}{D}\right)^{2.1} \exp \left(2.77 \frac{d}{D}\right)
$$

ただし、 $D$ は弦材の外径、 $T$ は弦材の管厚、 $d$ はウェブ材の外径で ある。

(22)～(27)式の総和として全鉛直変位は次式となる。

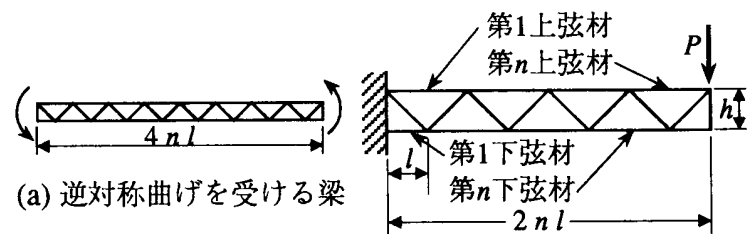

図7 考察対象

(b) 片持梁

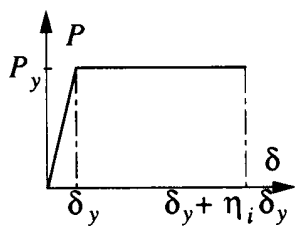

(a) 端部弦材による変形 (b) トラス全体の変形

図8 トラスの荷重-変形関係

$$
\Delta=\frac{16 n^{3} l^{3} P}{3 E A h^{2}}\left(1+\frac{1}{8 n^{2}}+\frac{3 A l_{W}{ }^{3}}{8 A_{W} n^{2} l^{3}}\right)+\frac{4 n-1}{E K} P
$$

端部弦材の奇与率は、(24)式の $\delta_{L 1}$ を上式の $\Delta$ で除した值として算 定できる。

4.3 トラス形状

ここでは、パネル数 $n=1 \sim 10$ 、弦材の径厚比 $D / T=15 \sim 50$ 、ウェ ブ材の径厚比 $d / t=10 \sim 50$ 、ウェブ材と弦材の外径比 $d / D=0.2 \sim$ 1.0、交角 $\theta=30 \sim 60$ 度、1パネルの弦材の細長比 $\lambda=10 \sim 50$ の範囲域 で寄与率を算定した。しかし、この範囲で自由に上記のパラメータ を変化させると、弦材が座屈しないトラスも含むことになり、また 非現実的な形状のトラスも含まれる。そこで、下記の4項目につい て検討し、これに適さない範囲は除外した。ただし、ヤング係数は $E=2100 \mathrm{t} / \mathrm{cm}^{2}$ とし、弦材の管厚は $T=10 \mathrm{~mm}$ で一定とした。また、弦 材、ウェブ材の降伏応力度 $\sigma_{y}, \sigma_{y w}$ は次式で与える ${ }^{15)} 。$

$$
\begin{aligned}
& \sigma_{y}=4.69(D / T)^{-0.0622} \\
& \sigma_{y W}=4.69(d / t)^{-0.0622}
\end{aligned}
$$

[1] 最大圧縮力を受ける第一下弦材が降伏するよりも先にウェブ材 の座屈、分岐継手の局部変形が生じない。

ウェブ材の座屈軸力 $N_{c}$ は鋼構造設計規準の短期許容圧縮応力度 を準用したが、 $F$ 值の代わりに上記の降伏応力度 $\sigma_{y w}$ を用い、座 屈長さ $l_{k W}$ は次式 ${ }^{18)}$ とした。

$$
\begin{aligned}
l_{k W} & =\min \left(k_{b 1} l_{W}, k_{b 2} l_{W 2}\right) \\
k_{b 1} & =1.19 /(r+2.40)+0.5 \\
k_{b 2} & =2.51 /(r+4.31)+0.5
\end{aligned}
$$

ただし、 $l_{W 2}$ はヴェブ材の弦材管壁間の長さであり、rは次式で表 される。

$$
\begin{aligned}
& r=\frac{l_{W} / E I_{W}}{1 / G_{0}+1 / E K_{0}} \\
& G_{0}=4 G I_{P} / 2 n l \\
& K_{0}=2040 D^{3} \exp \left\{(2.65 d / D-11)(D / T)^{0.15}\right\}
\end{aligned}
$$

ここで、Gはせん断弾性係数、 $I_{P}$ は弦材の断面極二次モーメン

ト、 $K_{0}$ は継手の回転剛性17)である。

接合部の局部変形耐力 $N_{U}$ は次式19)で与える。

$N_{U}=f_{0} f_{1} f_{2} f_{4} f_{5} f_{6} T^{2} \sigma_{y}$

ここで、 


$$
\begin{aligned}
& f_{0}=2.11(1+5.66 d / D) \\
& f_{1}=(D / T)^{0.209} \\
& f_{2}=1+\frac{0.00904(D / T)^{1.24}}{\exp \left(0.508 \frac{g-3.04}{T}-1.33\right)+1} \\
& f_{4}=\frac{1-0.376 \cos ^{2} \theta}{\sin \theta} \\
& f_{5}=\left(1-0.305 n_{0}-0.285 n_{0}^{2}\right) \quad\left(n_{0}=1\right) \\
& f_{6}=\left(\sigma_{y} / \sigma_{u}\right)^{-0.723}
\end{aligned}
$$

したがって、第一下弦材が降伏軸力に達するときのウェブ材軸力 が、座屈軸力 $N_{c}$ および $(31)$ 式による局部変形耐力 $N_{U}$ より小さい 範囲とする。

[2]1次設計時の地震層せん断力によって生じる各階の層間変形角は $1 / 200$ 以内20)である。トラス構造物の構造特性係数 $D_{S}$ 值を 0.5 以下 に設定することを前提として、2次設計用地震層せん断力によって 弾性限に達するとすると、弾性限層間変形角は $1 / 80$ 以下でなけれ ばならないことになる。トラス梁以外の構造要素が十分に剛であ るとしても、トラス梁端の弾性限回転角 $\theta_{y}$ は下記の範囲内にあ る。

$$
\theta_{y}=\frac{\Delta_{y}}{2 n l}<\frac{1}{200} \frac{0.5}{0.2}=\frac{1}{80}
$$

[3] 弦材とウェブ材の分岐継手部分のギャップ $g$ および偏心 $e$ が次に 示す制限内 21 にある。

$-20<g / T<40,-0.5 \leq e / D \leq 0.25$

[4] 梁せい $h$ が弦材の外径 $D$ の5倍以上である。

\section{4 第一下弦材の寄与率}

まず、断面二次モーメントが $A h^{2} / 2$ である梁として求めた全曲 げ変形が、トラス梁の全体変形に占める割合を曲げ変形率 $R_{F}$ と称 し、この值について検討する。

$$
R_{F}=\frac{16 n^{3} l^{3}}{3 E A h^{2}} \frac{P}{\Delta}
$$

図9には横軸にパネル数 $n$ をとり、それぞれのパネル数について

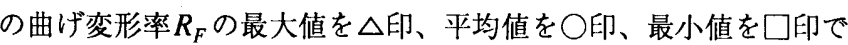
示す。眓9では、パネル数 $n$ が大きくなるほどトラスのせいに対す る長さが長くなり、曲げ変形率 $R_{F}$ が大きくなっている。ただし、 パネル数 $n$ が 3 より小さなると、 $R_{F}$ の最小值が大きくなっている のは、パネル数が小さくなるとウェブ材と弦材の軸力の比が大きく
なり、接合部で局部変形が生じ易いので、ウェブ材の断面が小さい 範囲は前項の条件[1]によって除外されるからである。 曲げ変形率 $R_{F}$ の平均值である○印を実線で近似する。すなわち、

$$
R_{F}=n /(n+0.8)
$$

(35)式を用いて第一下弦材の寄与率 $R_{E}$ は次式となる。

$$
R_{E}=R_{F} \times \frac{\frac{4 n^{2} l^{3}}{E A h^{2}}}{\frac{16 n^{3} l^{3}}{3 E A h^{2}}}=R_{F} \times \frac{3}{4 n}=\frac{3}{4(n+0.8)}
$$

(36)式の結果を図10に実線で示す。図中には、(24),(28)式より得た第

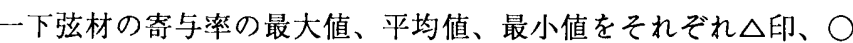
印、口印で示す。図10より、(36)式が第一下弦材の寄与率の平均値 を良好に近似していることが分かる

\section{5 第一下弦材の変形能力}

トラス梁端部弦材の変形能力は3節でも述べたように、同一細長 比、同一径厚比の中心圧縮柱よりも座屈後の軸力低下が緩やかで、 局部座屈発生時の軸方向変形も大きい。そこで本論では、中心圧縮 柱の変形能力を第一下弦材の変形能力 $\eta_{i}$ とする。筆者らは既に文献 10)において、単純支持の中心圧縮柱の局部座屈発生までの変形能力 を図11に破線で示すように定量化している。

図11には、径厚比 $D / T=10,20,30,50$ の場合について基準化細長 比 $\lambda_{b}$ と中心圧縮柱の変形能力 $\eta_{i}$ の関係を示している。ただし、

$$
\lambda_{b}=\lambda / \pi \sqrt{E / \sigma_{y}}
$$

なお、 $\sigma_{y}$ は(29)式の值、 $E$ は $2100 \mathrm{tf} / \mathrm{cm}^{2}$ としているので、 $\pi \sqrt{E / \sigma_{y}}$ は72 75程度の值である。

図11によると、中心压縮柱の変形能力 $\eta_{i}$ は、ある細長比で極小值 をとる性質があり、この值より細長比の小さい領域では細長比が大 きくなるほど変形能力が小さくなっている。図の右側を占めている 細長比が大きくなるほど変形能力が大きくなっている領域では、局 部座屈発生までに生じる主な軸方向変形成分は、たわみによる変形 であり、この領域では座屈後軸力の低下は著しくなる 論では、眓11の極小值より細長比の小さい領域のみに注目し、第一 下弦材の変形能力を次式で近似した。

$$
\eta_{i}=\frac{\left(29+2.5 D / T-220 \lambda_{b}\right)^{3}}{(D / T)^{3.33}}+\frac{1.33 \times 10^{4}}{(D / T+12.3)^{2.25}}
$$

ただし、細長比が極端に小さいとき、部材は曲げ座屈する前に局部 座屈することを考慮して、上式を使用する際に越智らの提案した短 柱圧縮試験の局部座屈発生時歪度の評価式15)を用いて、以下の制限
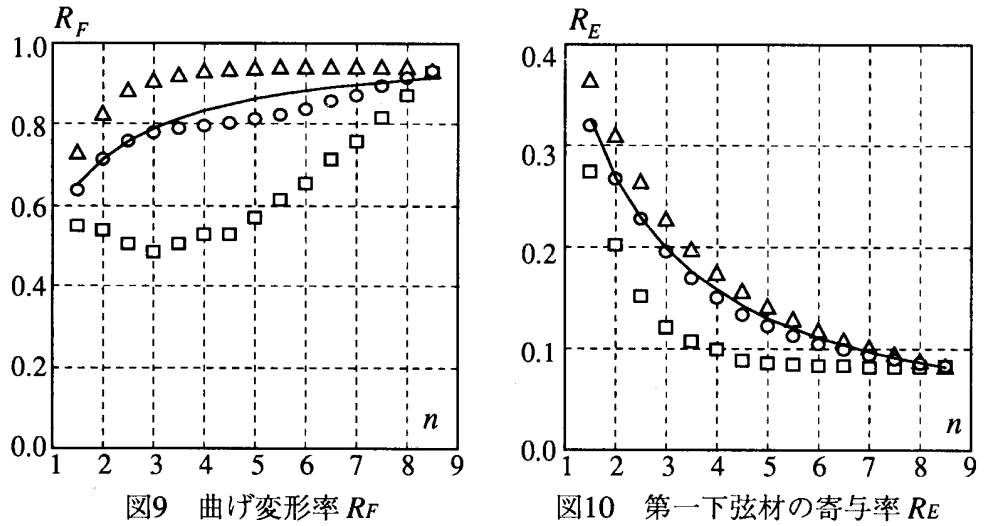

図10 第一下弦材の寄与率 $R E$

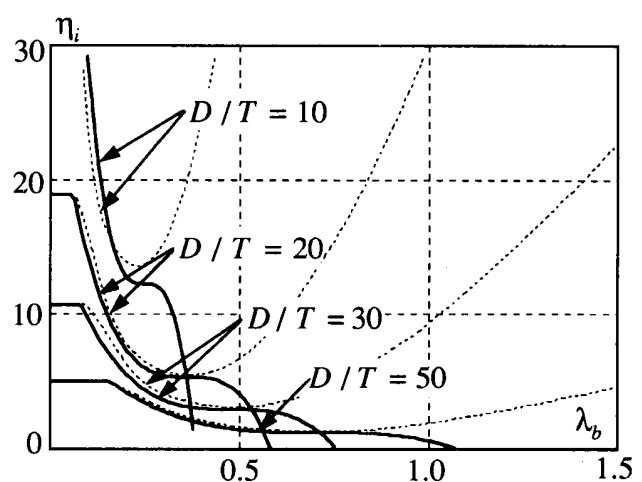

図11 第一下弦材の変形能力 $\eta_{i}$ 
を加える。

$$
\eta_{i} \leq \varepsilon_{m} / \varepsilon_{y}-1=0.205\left(\varepsilon_{y} D / T\right)^{-1.39}-1
$$

(38),(39)式の結果を図11に実線で示す。細長比の小さい領域で、 実線は破線で示す第一下弦材の変形能力をよく近似しており、例 えこの範囲を超えても变形能力 $\eta_{i}$ を過大に評価することはない。

\section{6 トラス梁の変形能力}

(21)式に従って、(38),(39)式に示す第一下弦材の変形能力 $\eta_{i} に$ (36)式に示した寄与率 $R_{E}$ を乗じることによって、トラス梁全体の 変形能力 $\eta$ は算定できる。

3節で示したF2,F3試験体についても、以上の式を用いて変形能力 を算定し、その結果を図6中に鎖線で示している。鎖線で示した(21) 式による算定值は、・印で示す2節の解析による局部座屈発生時変 形より更に小さくなっている。これは、これらの試験体が弦材座屈 を目的として設計されたもので、ウェブ材や分岐継手が比較的剛強 に設計されており、端部弦材の寄与率が(36)式による值より大きい ためである。

さて、(21),(36),(38),(39)式を用いて、トラスの変形能力が $\eta=0.5$, $1.0,1.5,2.0$ である時の弦材の径厚比 $D / T$ と基準化細長比 $\lambda_{b}$ の関係 を求め、それぞれ図12(a), (b), (c), (d)に示す。各図には、パネル数 $n$ が2,3,4,5についての結果を示している。図12によると、トラスの 変形能力 $\eta$ が大さくなるほど、細長比、径厚比は小さいものに限ら れており、全体を通して比較的小さな変形能力を対象としているに もかかわらず、部材の寸法制限は非常に厳しいものになることが分 かる。

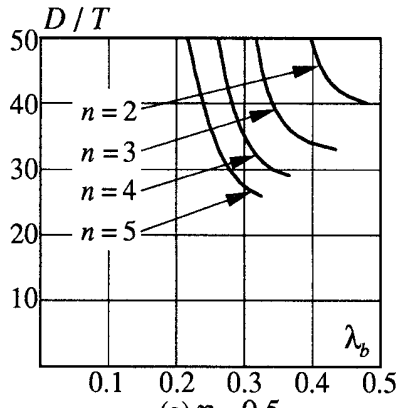

(a) $\eta=0.5$

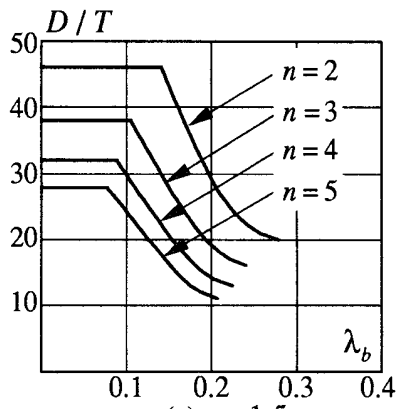

(c) $\eta=1.5$

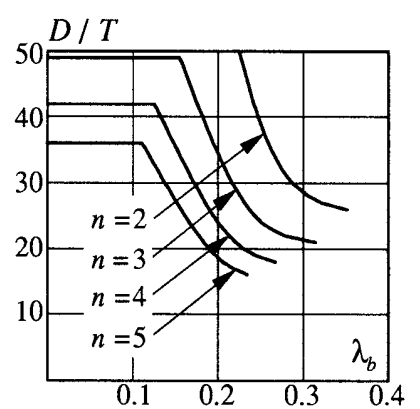

(b) $\eta=1.0$

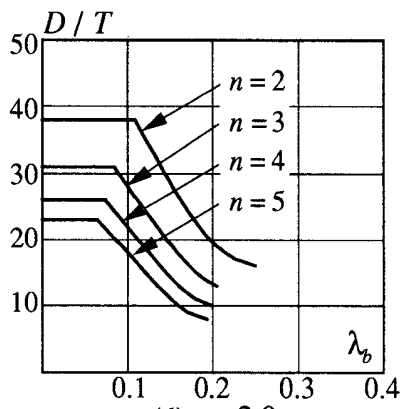

(d) $\eta=2.0$
図12 トラス梁の変形能力

\section{5. 結論}

本論では、韭線形歪硬化を考虑した弾塑性ヒンジを用いて鋼管卜 ラスの座屈後挙動を解析し、構面外座屈する弦材の端部1区間の軸 力-軸方向変形関係は、同じ細長比、径厚比の中心圧縮柱より、座 屈後の軸力低下が緩やかで局部座屈発生時の変形も大きくなること などを示した。また、このような結果に基づいて、弦材が構面外座
屈する鋼管トラスの変形能力の実用的な算定式を提示した。この算 定式から導かれる結果は、鋼管トラスに一定程度以上の塑性变形能 力を付与するには、かなり厳しい寸法制限が必要なことを示唆して いる。

\section{参考文献}

1) 鈴木敏郎、久保寺勲、小河利行：鉄骨トラスばりの酎力と塑性変形性状 に関する実験研究（トラス構造物の耐震性に関する研究 1)、日本建築学 会構造系論文報告集、第360号、75-83頁、1986.2

2) 鈴木敏郎、久保寺勲、小河利行：鉄骨トラス骨組の復元力特性と耐震性 評価方法（トラス構造物の耐震性に関する研究 2）、日本建筑学会構造系 論文報告集、第365号、28-39頁、1986.7

3）西山功：鉄骨トラス構造骨組の塑性変形能力（その1 鉄骨トラス部材の 塑性変形能力）、カラム、No.102、47～53頁、1986.10

4) 西山功：鉄骨トラス構造骨組の塑性変形能力（その2 鉄骨トラス架構の 塑性変形能力）、カラム、No.105、66 74頁、1877.1

5) 鈴木弘之：鍕卜ラス梁の終局耐力と変形能力、日本建築学会大会学術講 演梗概集、C構造II、1137-1138頁、1989.10

6) 日本建築学会：建築耐震設計における保有耐力と変形性能(1990), pp.295310, 1990

7) C. Matsui, S. Morino and A. Kawano : Lateral Tortional Buckling of Pipe Trusses, 3rd International Colloquium on Stability of Metal Structures, Liege, pp.101-108, 1983

8) 正井輝、小川厚治、黑羽啓明、角田光正 : 合成卜ラス下弦材の構面外座 屈長さに関する研究、日本建築学会大会学術講演梗概集、C構造II、13491352頁、 1993.9

9) 小川厚治、黑羽啓明、山成實 : 弦材の構面外座屈長さの実用算定法（繰 返し力をうける鋼管トラスの終局挙動 その3）、日本建築学会構造系論 文報告集、第443号、117-126頁、1993.1

10) 小川厚治、黒羽啓明、前田珠希 : 円形鋼管圧縮柱の座屈後挙動に関する 研究、日本建築学会構造系論文集、第475号、pp.137-144、1995.9

11) 北島博文、小川厚治、山成實、黑羽啓明、真有信博：弦材が座屈する鎆 管トラスばりの終局挙動に関する考察、日本建築学会中国・九州支部研 究報告、第8号、189-192頁、1990.3

12) 松井千秋、河野昭彦 : 円形鋼管トラス柱の曲げねじれ座屈に関する実験 的研究、日本建築学会構造系論文報告集、第363号、12-21頁、1986.5

13) 小川厚治、黑羽啓明、山成實：トラス個材の座屈長さと座屈強度に関す る研究（絽返し力をうける銅管トラスの終局挙動 その2）、日本建築学 会構造系論文報告集、第438号、157-164頁、1992.8

14) 小川厚治、黑羽啓明、山成實：実トラスの載荷実験における分岐継手の 挙動（絽返し力をうける銅管トラスの終局挙動 その1）、日本建築学会 構造系論文報告集、第433号、61-71頁、1992.3

15) 越智健之、黒羽啓明 : 冷間成形冈形鋼管部材の耐力と変形能の統計的評 価、日本建築学会構造系論文報告集、第391号、59-69頁、1988.6

16) 西村章、小川厚治、黒羽啓明：構面外座屈する銅管トラス弦材の座屈後 挙動に関する研究、龬構造年次論文集、第2巻、213-220頁、1994.11

17) 坂本傑、筫島仲男：八角形鋼管T形分岐継手の力学的性状、日本建築学 会大会学術講演梗概集、1037-1038頁、1979.9

18) 小川厚治、牧野雄二、山成實、黑羽啓明：鋼管トラスウェブ材の座屈長 さに関する研究、日本建築学会構造系論文報告集、第388号、70-75頁、 1988.6

19) Yoshiaki Kurobane,Yuji Makino and Kenshi Ochi : ULTIMATE RESISTANCE OF UNSTIFFENED TUBULAR JOINTS,ASCE,Journal of Structural Engineering ,Vol,110,No.2,February ,1984

20）日本建築センター、改正建築基準法施行令新耐震基準に基づく構造計算 指針・同解説、1981.9

21）日本建築学会、鋼管構造設計施工指針同解説、78頁、1990 